\title{
Compartments of organic matter in an Oxisol under different types of no-tillage systems
}

\section{Compartimentos da matéria orgânica de um Latossolo sob diferentes tipos de semeadura direta ${ }^{1}$}

\author{
Roni Fernandes Guareschi ${ }^{1 *}$; Marcos Gervasio Pereira ${ }^{2}$; Paula Fernanda Chaves \\ Soares $^{3}$; Fabiana da Costa Barros ${ }^{4}$; Adriano Perin ${ }^{5}$; Celeste Queiroz Rossi ${ }^{6}$
}

\begin{abstract}
The objective of this study was to evaluate the changes in soil carbon (C) as well as its fractions of physical (particulate organic carbon associated with minerals), chemical (fulvic and humic acids and humins), and oxidizable (F1, F2, F3, and F4) forms of an Oxisol under no-tillage systems (SPD) under different successions and crop rotations in the Cerrado area. In order to do this, the areas of consolidated SPD (10 to 20 years) under the same soil and climatic conditions were selected in Montividiu (GO), with soybean-corn succession (SSM), soybean-millet succession (SSMt), soybean-millet-bean-cotton rotation (RSMFA), crop-livestock integration (ILP), and a native cerrado (CE) area used as a control treatment In each area, samples were collected at depths of 0.0-0.05, 0.05-0.10, 0.10-0.20, and 0.20$0.40 \mathrm{~m}$, respectively. The no-tillage system with crop rotation, followed by no-tillage system with crop-livestock integration, were the ones that presented the greatest potential to increase total carbon content in soil, presenting higher $\mathrm{C}$ contents of the granulometric, humic, and oxidizable fractions of the soil organic matter (SOM), compared with the other areas of no-tillage systems with succession of the respective evaluated crops. The no-tillage areas with corn and soybean/millet succession systems showed a similar pattern in soil $\mathrm{C}$ accumulation, as well as in the compartments of SOM evaluated.
\end{abstract}

Key words: Soil carbon. Humic substance. Physical fractionation. Cerrado.

\section{Resumo}

O objetivo deste estudo foi avaliar as alterações no carbono do solo, bem como, suas frações físicas (carbono orgânico particulado e associado aos minerais), químicas (ácido fúlvico, húmico e humina), e oxidáveis (F1, F2, F3 e F4) de um Latossolo Vermelho em áreas de sistema de plantio direto (SPD) sob diferentes sucessões e rotações de culturas no cerrado goiano. Para isso, em Montividiu (GO) foram selecionadas áreas de SPD consolidado (10 a 20 anos) sob mesmas condições edafoclimáticas com: sucessão soja-milho (SSM), sucessão soja-milheto (SSMt), rotação soja-milho-milheto-feijãoalgodão (RSMFA), integração lavoura-pecuária (ILP) e uma área de cerrado nativo (CE) utilizada como referência. Em cada uma das áreas, foram coletadas amostras nas profundidades de $0,0-0,05 ; 0,05$ -

${ }^{1}$ Dr., Pós-Doutorando em Fitotecnia, Curso de Pós-Graduação em Fitotecnia, Universidade Federal Rural do Rio de Janeiro, UFRRJ, Seropédica, RJ, Brasil. E-mail: guareschiecotarelli@hotmail.com

2 Prof. Dr., Departamento de Solos, UFRRJ, Seropédica, RJ, Brasil. E-mail: mgervasiopereira@gmail.com

${ }^{3}$ Dr., Pós-Doutorando em Agronomia, Curso de Pós-Graduação em Agronomia - Ciência do Solo, UFRRJ, Seropédica, RJ, Brasil. E-mail: pfernanda07@gmail.com

${ }^{4}$ Discente, Curso de Graduação em Engenharia Agrícola e Ambiental, UFRRJ, Seropédica, RJ, Brasil. E-mail: barros.faby@ hotmail.com

5 Prof. Dr., Departamento de Fitotecnia, Instituto Federal Goiano, IFGoiano, Campus Rio Verde, Rio Verde, GO, Brasil. E-mail: perinrj@yahoo.com.br

${ }^{6}$ Prof. Dr., Universidade Federal do Oeste do Pará, UFOPA, Campus Juruti, PA, Brasil. E-mail: celesteqrossi@gmail.com

* Author for correspondence 
0,$10 ; 0,10-0,20 ; 0,20-0,40 \mathrm{~m}$. O sistema de plantio direto com rotação de culturas seguido do sistema de plantio direto com integração lavoura-pecuária foram aqueles que apresentaram maior potencial de aumento do carbono total do solo, apresentando maiores teores de $\mathrm{C}$ das frações granulométricas, húmicas e oxidáveis da MOS (matéria orgânica do solo) em relação as demais áreas de sistema de plantio direto com sucessão de culturas avaliadas. As áreas de sistema de plantio direto com sucessão soja/milho e soja/milheto exibiram padrão semelhante no acúmulo de $\mathrm{C}$ do solo, bem como, nos compartimentos da MOS avaliados.

Palavras-chave: Carbono do solo. Substância húmicas. Fracionamento físico. Cerrado.

\section{Introduction}

Use of the no-tillage system (NTS) has increased in the Cerrado as an alternative measure to minimize the negative impacts on soil caused by different cropping systems, since keeping the plant residues on the surface, crop rotation (CR), and minimal soil disturbance (only in the sowing pit), which are basic principles in NTS, can change the soil organic matter quantity and quality, enhancing soil fertility and physical features (ROZANE et al., 2010; GUARESCHI et al., 2012a,b).

It should be noted that a cropping system refers to management practices associated with a specific plant species, with the aim of producing it through a logical and orderly combination of activities and operations (HIRAKURI et al., 2012). For example, in the NTS, there are management practices that are common, but the decision of adopting (or not adopting) some of them (mainly selection of the crop sequence) leads to variations in this system. However, in the cerrado regions, crop rotation (CR), one of the basic principles of NTS, has been replaced by crop succession (CS), mainly due to the limited number of crops that are economically viable for the autumn/winter season (CARNEIRO et al., 2013). The predominating CSs in the NTS areas in these regions are soybean or corn in summer followed by corn, sorghum, millet, or fallow in autumn (BRESSAN et al., 2013; CAETANO et al., 2013).

Studies have shown that, in some situations, the NTS with soybean/safrinha corn succession provides inadequate and insufficient soil coverage (MARIA et al., 2012; CARNEIRO et al., 2013; CECCON et al., 2013), which, over time, results in lower soil carbon content compared to NTS with CR (CAMPOS et al., 2011; FRANCHINI et al., 2011).

However, when assessing NTS areas with soybean/safrinha corn succession, increases in total carbon (MARCELO et al., 2009; SIQUEIRA NETO et al., 2010; GUARESCHI et al., 2012a; ROSSET et al., 2016; SEBEN JUNIOR et al., 2016), humic acid, humin, mineral-associated carbon contents (GUARESCHI et al., 2013b; GAZOLLA et al., 2015; ROSSET et al., 2016), and oxidizable fractions (GUARESCHI et al., 2013a; ROSSET et al., 2016) were observed depending on the time NTS was been adopted, compared to other NTS variations. These contrasting results, i.e., increase or decrease in soil organic matter (SOM) in the NTS with or without $\mathrm{CR}$, highlight the need to compare areas of consolidated NTS with CS and CR in the Goiás Cerrado in order to clarify the changes these management strategies induce in the chemical and physical properties of the soil as well as in SOM dynamics.

Soybean/millet succession is another type of management practice suggested as a good alternative for the NTS in the cerrado region (BRESSAN et al., 2013; CAETANO et al., 2013). Soybean/millet succession has yielded dry mass (straw) above the minimum quantity $\left(10 \mathrm{Mg} \mathrm{ha}^{-1}\right)$ required to adopt the NTS in the cerrado (BRANCALIÃO et al., 2007; BRANCALIÃO; MORAES, 2008; CARNEIRO et al., 2013), thus increasing the organic matter content in Oxisols (PEREIRA et al., 2010; BRESSAN et al., 2013) and/or maintaining a carbon content similar to that found in the native cerrado depending on the time the NTS was applied to Entisols (CAETANO et al., 2013). In addition to increasing SOM content, 
Brancalião and Moraes (2008) highlight the fact that this type of succession promotes greater carbon increase in the organic matter fractions that are less stable (humic and fulvic acids). Research results demonstrating the dynamics of the granulometric and oxidizable fractions in this type of succession in a NTS in comparison to other forms of soil management or conservation in the cerrado are scarce. These results show that the soybean/millet succession can provide several benefits to the soil, but studies assessing its efficiency in comparison to other types of CS and CR in cerrado Oxisols are scarce.

Another mode of NTS that has been developed in the cerrado over the past few years is the croplivestock integration (CLI) system. Regarding soil carbon, studies have shown that CLI tends to increase its stock, sometimes even matching and/ or exceeding the values found in areas of native cerrado vegetation (CE) and NTS without grazing (SOUZA et al., 2009; LOSS et al., 2012; GAZOLLA et al., 2013; ROSSET et al., 2016; BIELUCZYK et al., 2017). Among the reasons for this increase, one that stands out is the association of several factors acting together, including high dry mass production by the aerial parts and roots of Brachiaria grasses, the contribution of bovine waste, deposition of residues from annual crops, and the fertilization employed (SOUZA et al., 2009; LOSS et al., 2012; BIELUCZYK et al., 2017). However, according to Souza et al. (2009), the intensity of grazing applied in CLI must be optimized because highly intensive grazing may reduce the $\mathrm{C}$ and $\mathrm{N}$ stocks due to degradation of the organic matter.

The research results of the humic fractions have also been contradictory, i.e., some studies show that adoption of CLI leads to increased formation of recalcitrant substances (humin and/or humic acids) compared to NTS without CLI (LOSS, 2011; ROSSI et al., 2011; SILVA et al., 2011; BEZERRA et al., 2013; GAZOLLA et al., 2015), while other studies report an inverse result with the humic factions having lower C content in CLI areas in comparison to NTS (ROSSET et al., 2016). This effect may result from several factors, among which the main ones are the time of time the systems have been applied for and different edaphoclimatic conditions.

Ambiguity is also found in the results of granulometric fractionation of SOM, with similar fractions being found for areas with CLI and NTS without CLI (BIELUCZYK et al., 2017), but also high particulate organic carbon (POC and/or mineral-associated organic carbon (OCma) contents in areas with CLI compared to NTS without CLI (LOSS, 2011; ROSSI et al., 2012; GAZOLLA et al., 2015).

Regarding the oxidizable fraction of SOM, which is relevant to differentiate soil quality, it has been shown that CLI areas provide a better balance in carbon accumulation in the labile and recalcitrant SOM fractions (ROSSET et al., 2016; BIELUCZYK et al., 2017). However, the number of studies that compare the dynamics of these fractions in cerrado areas with consolidated NTS with and without CLI is limited.

Considering the discussion above, it is clear that there is a need to identify and use cropping systems that provide good soil coverage, with high economic return, in order to improve and/or maintain soil quality and crop productivity. In literature, it is also clear that, when assessed alone, NTS with CR, soybean/safrinha corn or soybean/millet CS, and CLI potentially increase SOM content and therefore might change some physical and chemical attributes of the soil. However, due to the lack of studies, it is important to assess these management strategies all together under consolidated NTS in the cerrado so that their long-term efficiency can be evaluated considering both soil carbon and the chemical and physical fractions of SOM.

In this context, the aim of this study was to assess the changes in soil carbon as well as its physical (particulate organic carbon (OCp) and mineralassociated organic carbon (OCma)), chemical (humic acid, fulvic acid, and humin), and oxidizable 
(F1, F2, F3, and F4) fractions of an Oxisol in areas with consolidated NTS with soybean/corn succession (SCS), soybean/millet succession (SMS), soybean/corn/millet/beans/cotton rotation (SCMBCR), and crop-livestock integration (CLI), along with a native cerrado (CE) area used as a reference.

\section{Material and Methods}

Soil samples were collected in two rural regions in the municipality of Montividiu-GO (17 $27^{\prime} 52.2^{\prime \prime}$ $\mathrm{S}$; 51 ${ }^{\circ} 10^{\prime} 33.1^{\prime \prime} \mathrm{W}$; altitude $890 \mathrm{~m}$ ). The region has a rainy tropical climate; Aw type in the Köppen climate classification. It has two distinct seasons-the rainy season (October to April) and the dry season (May to September). The average temperature is $22^{\circ} \mathrm{C}$, and the average annual rainfall is $1740 \mathrm{~mm}$. The soils in the areas studied were classified as typical Latossolo Vermelho Distroférrico (Oxisol).

Four farming areas were selected: NTS with soybean/safrinha corn succession (SCS); NTS with soybean/millet succession (SMS); NTS with soybean/corn/brachiaria grass succession (SCBS) in integrated crop-livestock management; and NTS with soybean/corn/millet/beans/cotton rotation (SCMBCR). Samples were also collected from a cerrado area adjacent to the farming areas.

The native cerrado area was used as a reference because it is a system that has not been subjected to anthropic action. The cerrado area analyzed is located within the Fazenda Vargem Grande reserve

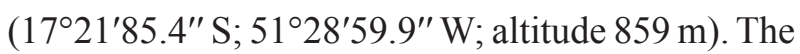
SCS area $\left(17^{\circ} 08^{\prime} 59.8^{\prime \prime} \mathrm{S} ; 51^{\circ} 11^{\prime} 23.4^{\prime \prime} \mathrm{W}\right.$; altitude $885 \mathrm{~m})$ is located in Fazenda Estreito Ponte de Pedra; it was opened in 1981 with cerrado removal and it has been cultivated under NTS with soybean in summer and safrinha corn for 16 years. The SMS area $\left(17^{\circ} 18^{\prime} 28.6^{\prime \prime} \mathrm{S} ; 51^{\circ} 15^{\prime} 21.8^{\prime \prime} \mathrm{W}\right.$; altitude $\left.853 \mathrm{~m}\right)$ is also located in Fazenda Estreito Ponte de Pedra, and has a history of 33 years of cultivation, with the NTS being adopted in 1998 after conventional system of soybean planting in summer. This area was cultivated under NTS with soybean in summer and safrinha corn until 2004, and with SMS since then.

The SCBS and SCMBCR areas are located in Fazenda Vargem Grande, owned by Agropecuária Peeters (17²1'85.4" S; 51²8'59.9" W; altitude $859 \mathrm{~m})$. The NTS area with SCBS was cultivated with soybean in summer, safrinha corn intercalated with brachiaria grass, and with grazing. Finally, the SCMBCR area started to be used in 1975, with cerrado removal and forage cultivation for 10 years. Subsequently, conventional cultivation of soybean and corn was carried out for 10 years, and for 19 years now it has been cultivated under NTS with the following crop rotation: soybean/corn/millet/beans/ cotton. The sequence of this CR underwent slight variation over the years according to the economic viability of each crop.

All NTS areas assessed are considered to be in the system consolidation phase (10 to 20 years). In all of them, before the NTS was initiated, the soil under conventional system was prepared as follows: 1) first, scarification and/or subsoiling were performed at 35 to $40 \mathrm{~cm}$ depth to facilitate deep plowing; and 2) next, a heavy harrow was used (36" discs); then 3) soil preparation was finalized by using an intermediate harrow. After this initial preparation, minimal soil disturbance was implemented (only in the sowing line/pit). The basic fertilization of the main crops in the agricultural systems was the following: 1) SCS-a) soybean (summer): potassium chloride at $165 \mathrm{~kg} \mathrm{ha}^{-1}$ applied prior to sowing, and 09-43-00 formulation (N-P-K) at $186 \mathrm{~kg} \mathrm{ha}^{-1}$ applied in the sowing groove; b) safrinha corn: 0728-14 formulation applied at $450 \mathrm{~kg} \mathrm{ha}^{-1}$ at planting, and urea applied at $100 \mathrm{~kg} \mathrm{ha}^{-1}$ by top dressing at 25 days after emergence (DAE); 2) SMS-a) soybean (summer): potassium chloride applied at $165 \mathrm{~kg} \mathrm{ha}^{-1}$ prior to sowing, and 09-43-00 formulation applied in the sowing groove at the rate of $190 \mathrm{~kg} \mathrm{ha}^{-1}$; b) millet: grown without fertilization; 3) SCBS-a) soybean (summer): 02-20-20 formulation applied at $475 \mathrm{~kg} \mathrm{ha}^{-1}$; b) safrinha corn: 07-28-14 formulation 
applied at $450 \mathrm{~kg} \mathrm{ha}^{-1}$ at planting, and urea applied at $100 \mathrm{~kg} \mathrm{ha}^{-1}$ by top dressing at $25 \mathrm{DAE}$; c) brachiaria grass was grown with no fertilization; 4) SCMBCR-a) soybean (summer): 02-20-18 formulation was applied at $550 \mathrm{~kg} \mathrm{ha}^{-1}$; b) safrinha corn: 07-28-14 formulation was applied at $450 \mathrm{~kg}$ $\mathrm{ha}^{-1}$ at planting, and urea was applied at the rate of $100 \mathrm{~kg} \mathrm{ha}^{-1}$ by top dressing at $25 \mathrm{DAE}$; c) millet was grown with no fertilization; d) beans: 05-20-10 formulation was applied at the rate of $400 \mathrm{~kg} \mathrm{ha}^{-1}$ at planting, and urea was applied at the rate of $90 \mathrm{~kg}$ $\mathrm{ha}^{-1}$ by top dressing at 25 DAE; e) cotton: 10-30-10 formulation was applied at $500 \mathrm{~kg} \mathrm{ha}^{-1}$ at planting, and 20-00-20 formulation was applied at $250 \mathrm{~kg} \mathrm{ha}^{-1}$ by top dressing .

The NTS areas with SCS, SMS, and SCBS were subjected to liming, in 2014, 2014, and 2013 through surface application at the following rates: 300 to $2800 \mathrm{~kg} \mathrm{ha}^{-1}$ (changing application rate), $2000 \mathrm{~kg} \mathrm{ha}^{-1}$, and $4000 \mathrm{~kg} \mathrm{ha}^{-1}$, respectively.

A representative 2.25 ha $(150 \times 150 \mathrm{~m})$ plot was established in each area, and five trenches of approximately $1 \times 1 \mathrm{~m}$ surface area and $0.40 \mathrm{~m}$ depth were made, randomly, in each area.

Subsequently, in each trench in the different areas, undisturbed soil samples were collected at $0-0.05,0.05-0.10,0.10-0.20$, and $0.20-0.40 \mathrm{~m}$ depths by using a volumetric ring (DONAGEMA et al., 2011). The samples were air-dried, any lumps were smashed, and the soil was passed through a $2 \mathrm{~mm}$ mesh sieve to obtain the air-dried fine soil (ADFS), which was used for chemical characterization and granulometric analysis (DONAGEMA et al., 2011) (Table 1).

Table 1. Chemical attributes and granulometric analysis at different soil depths of the evaluated areas.

\begin{tabular}{|c|c|c|c|c|c|c|c|c|c|c|}
\hline \multirow{2}{*}{ *Áreas } & $\mathrm{pH}$ & $\mathrm{P}$ & $\mathrm{Ca}$ & $\mathrm{Mg}$ & $\mathrm{K}$ & $\mathrm{Al}$ & $\mathrm{H}+\mathrm{Al}$ & Clay & Silt & Sand \\
\hline & $\mathrm{H}_{2} \mathrm{O}$ & $\mathrm{mg} \mathrm{kg}^{-1}$ & \multicolumn{5}{|c|}{ - } & \multicolumn{3}{|c|}{ 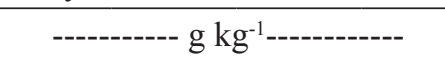 } \\
\hline & \multicolumn{10}{|c|}{$0.0-0.05 \mathrm{~m}$} \\
\hline $\mathrm{CE}$ & 5.0 & 2 & 3.1 & 1.8 & 0.2 & 0.2 & 8.4 & 420 & 420 & 159 \\
\hline SCS & 5.7 & 24 & 2.3 & 2.5 & 0.3 & 0.0 & 3.3 & 579 & 290 & 130 \\
\hline SMS & 6.2 & 16 & 3.8 & 1.8 & 0.1 & 0.0 & 2.3 & 449 & 368 & 182 \\
\hline SCBS & 5.9 & 27 & 4.3 & 2.3 & 0.2 & 0.0 & 2.7 & 532 & 245 & 222 \\
\hline \multirow[t]{2}{*}{$\begin{array}{c}\text { SCMB- } \\
\text { CR }\end{array}$} & 5.6 & 25 & 3.6 & 2.4 & 0.2 & 0.0 & 4.0 & 450 & 345 & 203 \\
\hline & \multicolumn{10}{|c|}{$0.05-0.10 \mathrm{~m}$} \\
\hline $\mathrm{CE}$ & 4.8 & 2 & 1.2 & 1.0 & 0.1 & 0.2 & 8.5 & 422 & 427 & 149 \\
\hline SCS & 5.1 & 21 & 0.8 & 1.1 & 0.2 & 0.0 & 3.8 & 537 & 304 & 158 \\
\hline SMS & 5.5 & 35 & 1.1 & 1.3 & 0.1 & 0.0 & 5.7 & 476 & 385 & 138 \\
\hline SCBS & 5.8 & 21 & 4.3 & 1.5 & 0.2 & 0.0 & 3.3 & 579 & 226 & 193 \\
\hline \multirow[t]{2}{*}{$\begin{array}{c}\text { SCMB- } \\
\text { CR }\end{array}$} & 5.3 & 13 & 2.4 & 1.4 & 0.1 & 0.0 & 4.0 & 478 & 376 & 145 \\
\hline & \multicolumn{10}{|c|}{$0.10-0.20 \mathrm{~m}$} \\
\hline $\mathrm{CE}$ & 4.9 & 2 & 0.4 & 0.6 & 0.1 & 0.2 & 7.0 & 432 & 451 & 116 \\
\hline SCS & 5.2 & 5 & 0.6 & 0.4 & 0.2 & 0.0 & 4.5 & 590 & 295 & 114 \\
\hline SMS & 5.6 & 12 & 1.1 & 0.8 & 0.1 & 0.0 & 4.9 & 502 & 377 & 119 \\
\hline
\end{tabular}

continue 
continuation

\begin{tabular}{ccccccccccc} 
SCBS & 5.6 & 12 & 2.1 & 1.8 & 0.2 & 0.0 & 5.5 & 591 & 243 & 165 \\
$\begin{array}{c}\text { SCMB- } \\
\text { CR }\end{array}$ & 5.0 & 5 & 0.9 & 1.0 & 0.1 & 0.0 & 4.3 & 487 & 368 & 144 \\
\hline & & & $0.20-0.40 \mathrm{~m}$ & & & & \\
\hline CE & 4.9 & 2 & 0.1 & 0.5 & 0.1 & 0.2 & 5.2 & 428 & 434 & 137 \\
SCS & 5.1 & 2 & 0.3 & 0.6 & 0.1 & 0.1 & 3.6 & 591 & 311 & 97 \\
SMS & 5.5 & 3 & 0.9 & 0.8 & 0.1 & 0.0 & 3.8 & 499 & 389 & 111 \\
SCBS & 5.2 & 2 & 0.6 & 0.6 & 0.1 & 0.0 & 2.7 & 595 & 268 & 136 \\
SCMB- & 5.0 & 2 & 0.3 & 1.0 & 0.1 & 0.0 & 3.5 & 498 & 337 & 164 \\
CR & & & & & & & &
\end{tabular}

"SMS-area under NTS with soybean/millet succession. ${ }^{* *}$ CE-native cerrado. ${ }^{* *}$ SCS-area under NTS with soybean/corn succession. ${ }^{* *}$ SCBS-area under NTS with soybean/corn/brachiaria grass succession. ${ }^{* *}$ SCMBCR-area under NTS with soybean/corn/beans/ cotton rotation.

C contents were quantified by dry combustion in a CHNS analyzer (Elementar Analysensysteme GmbH, Hanau, Germany).

The granulometric fractionation of SOM was performed according to Cambardella and Elliot (1992). Approximately $20 \mathrm{~g}$ of soil and $60 \mathrm{ml}$ of sodium hexametaphosphate solution $\left(5 \mathrm{~g} \mathrm{~L}^{-1}\right)$ were stirred for $15 \mathrm{~h}$ on a horizontal shaker. The suspension was then passed through a $53 \mu \mathrm{m}$ sieve. The material retained on the sieve, particulate organic carbon, was oven dried at $50^{\circ} \mathrm{C}$, weighed, ground using a porcelain pestle and mortar, and analyzed for $\mathrm{C}$ content by dry combustion in a CHNS analyzer (Elementar Analysensysteme $\mathrm{GmbH}$, Hanau, Germany). The (OCma) was obtained from the difference between total C and OCp.

The differential solubility technique (SWIFT, 1996) adapted by Benites et al. (2003) was used for sample extraction and chemical fractionation, the organic carbon being obtained in the fulvic acid fraction (C-FAF), humic acid fraction (C-HAF), and humin (C-HUM). In this method, $\mathrm{C}$ is determined by oxidation.

Finally, to determine the oxidizable fraction of SOM, only the soils collected at 0-0.05 and 0.05-0.10 $\mathrm{m}$ depths were used because practical experience showed that these are the depths at which this variable presents more significant values.
The methodology by Chan et al. (2001) was used in this analysis, where soil samples of $0.3 \mathrm{~g}$ were placed in $250 \mathrm{~mL}$ Erlenmeyer flasks, to which $10 \mathrm{ml}$ of $\mathrm{K}_{2} \mathrm{Cr}_{2} \mathrm{O}_{7}\left(0.167 \mathrm{~mol} \mathrm{~L}^{-1}\right)$ and amounts of $\mathrm{H}_{2} \mathrm{SO}_{4}$ p.a. corresponding to $3,6,9$, and $12 \mathrm{~mol} \mathrm{~L}^{-1}$ were added. Oxidation was carried out with no external heat source, and titration of the extracts was performed with a $\mathrm{Fe}\left(\mathrm{NH}_{4}\right)_{2}\left(\mathrm{SO}_{4}\right)_{2} \cdot 6 \mathrm{H}_{2} \mathrm{O}(0.4 \mathrm{~mol}$ $\left.\mathrm{L}^{-1}\right)$ solution, using phenanthroline $\left(\mathrm{C}_{12} \mathrm{H}_{8} \mathrm{~N}_{2} \cdot \mathrm{H}_{2} \mathrm{O}\right)$ as indicator, prepared by mixing $1.465 \mathrm{~g}$ of the indicator with $0.985 \mathrm{~g}$ of $\mathrm{Fe}\left(\mathrm{NH}_{4}\right)_{2}\left(\mathrm{SO}_{4}\right)_{2} \cdot 6 \mathrm{H}_{2} \mathrm{O}$, which were dissolved in $100 \mathrm{~mL}$ of distilled water. C-fractionation produces four fractions with decreasing oxidation degrees:

- Fraction 1 (F1): C oxidized by $\mathrm{K}_{2} \mathrm{Cr}_{2} \mathrm{O}_{7}$ in an acidic medium with $3 \mathrm{~mol} \mathrm{~L}^{-1} \mathrm{H}_{2} \mathrm{SO}_{4}$.

- Fraction 2 (F2): difference between $\mathrm{C}$ oxidized by $\mathrm{K}_{2} \mathrm{Cr}_{2} \mathrm{O}_{7}$ in an acidic medium with 6 and 3 $\mathrm{mol} \mathrm{L}^{-1} \mathrm{H}_{2} \mathrm{SO}_{4}$.

- Fraction 3 (F3): difference between $\mathrm{C}$ oxidized by $\mathrm{K}_{2} \mathrm{Cr}_{2} \mathrm{O}_{7}$ in an acidic medium with 9 and 6 $\mathrm{mol} \mathrm{L}^{-1} \mathrm{H}_{2} \mathrm{SO}_{4}$.

- Fraction 4 (F4): difference between $\mathrm{C}$ oxidized by $\mathrm{K}_{2} \mathrm{Cr}_{2} \mathrm{O}_{7}$ in acidic medium with 12 and $9 \mathrm{~mol}$ $\mathrm{L}^{-1} \mathrm{H}_{2} \mathrm{SO}_{4}$.

A fully randomized experimental design with five replicates for each area and depth was used. 
In all cases, the normality of the data (Lilliefors) and the homogeneity of variance (Cochran and Barttlet test) were assessed. The data were then subjected to analysis of variance with least significant difference (LSD) test, and average values were compared by the $t$ test at $5 \%$ probability using the Assistat statistical software.

\section{Results and Discussion}

At the soil surface $(0.0-0.05 \mathrm{~m})$, the $\mathrm{CE}$ area had higher $\mathrm{C}$ content compared to the other areas assessed (Figure 1). Higher $\mathrm{C}$ content in the $\mathrm{CE}$ area was due to a larger contribution of plant residues related to the vegetation in the area, associated with the absence of anthropic action. Similar results were reported by Guareschi et al. (2012a), Tirloni et al. (2012), and Gazolla et al. (2015), who found higher $\mathrm{C}$ contents in areas with native vegetation compared to areas with CLI and NTS.

Figure 1. Total soil organic carbon (C) contents at different depths in the areas assessed. Averages followed by the same letter in the columns and for each depth are not significantly different among the systems assessed based on a $t$ test at 5\% probability. SMS-area under NTS with soybean/millet succession. CE-native cerrado. SCS-area under NTS with soybean/corn succession. SCBS-area under NTS with soybean/corn/brachiaria grass succession. SCMBCR-area under NTS with soybean/corn/beans/cotton rotation.

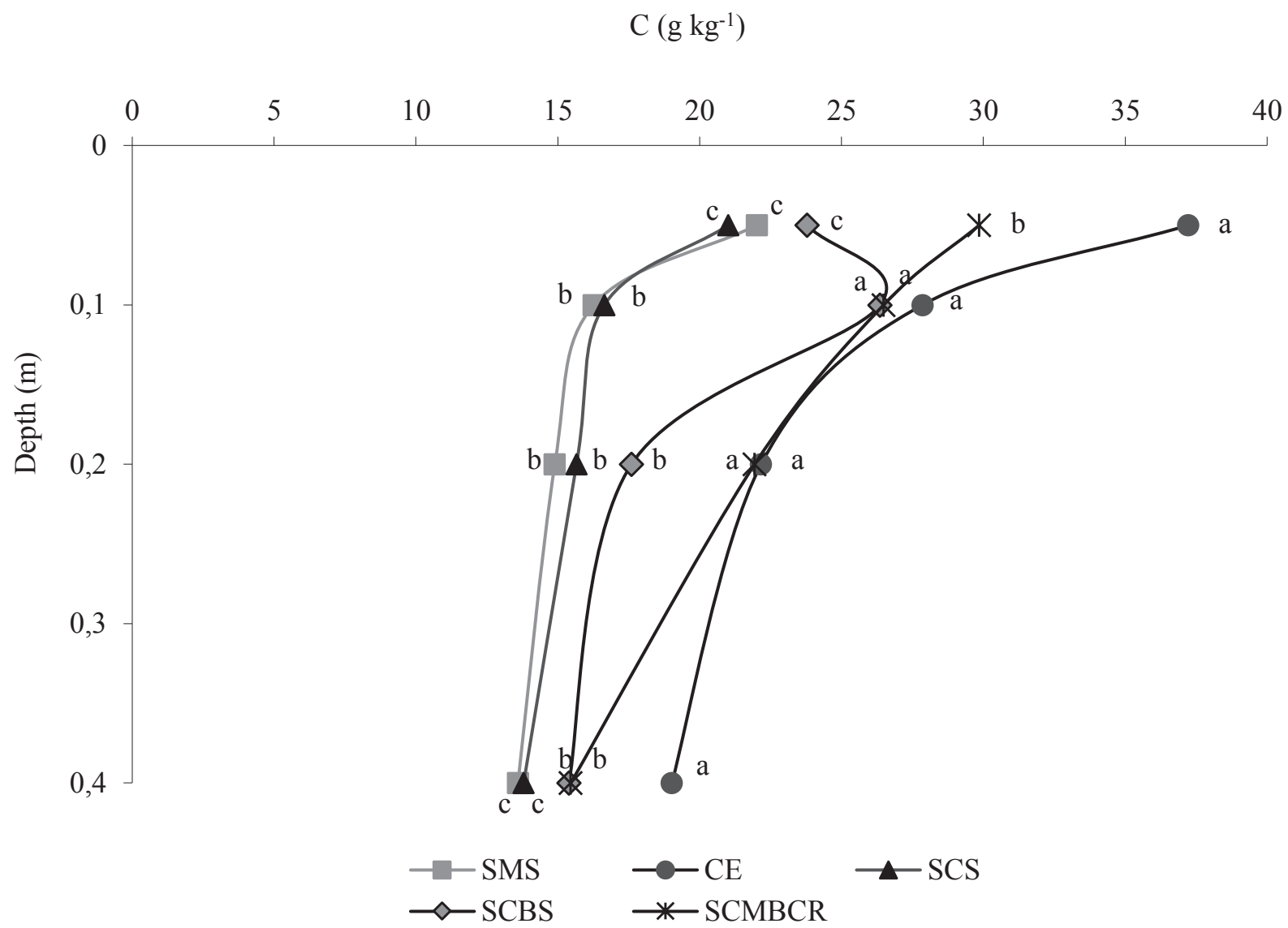


Also at the 0.0-0.05 $\mathrm{m}$ depth, the SCMBCR area was observed to have 29,26 , and $20 \%$ more $C$ than the other cultivated areas (SCS, SMS, and SCBS, respectively) (Figure 1). According to Franchini et al. (2011), this occurs because crop rotation provides increased addition of phytomass (roots and aerial parts) to the soil, which, together with the adoption of NTS, results in the increase in SOM content. In addition to the difference in the quantity of phytomass added to the soil, other factors that contribute to the increased carbon content are the different crops in rotation, because they contribute to the soil under NTS with organic materials with different qualities $(\mathrm{C} / \mathrm{N}$ ratio and lignin and polyphenol contents, among others) that change their decomposition rates. Similar results were obtained by Franchini et al. (2011) and Campos et al. (2011), who compared NTS areas with CR with areas with $\mathrm{CS}$, also observing higher $\mathrm{C}$ contents in the areas with rotation.

In general, the area with SCMBCR was superior to the areas with SCS and SMS in terms of C content (at all depths) (Figure 1). The same was observed for the $\mathrm{C}$ content in the SCBS area (0.05-0.10 and 0.20-0.40 m depths) compared to the SCS and SMS areas (Figure 1). It can be inferred that these results were due to the larger number and variety of species grown in the SCMBCR and SCBS areas compared to the crop successions studied. According to Campos et al. (2011), accumulation of $\mathrm{C}$ in the soil increases with the diversification of the cropping system. Therefore, the inclusion of species with an extensive root system and the long-term input of different types of crop residues in the soils managed under NTS linked to CR increased the content of $\mathrm{C}$ in soil, with higher lability (CONCEIÇÃO et al., 2005).

It is also worth noting the similarity of the $\mathrm{C}$ contents $(0-0.05,0.05-0.10$, and $0.10-0.020 \mathrm{~m}$ depths) in the SCMBCR and SCBS areas compared to the CE (Figure 1). This result shows that those soil management practices had a positive impact on soil quality, promoting the recovery of soil $\mathrm{C}$ contents to the original pre-cultivation conditions.

The CE area had higher content of OCp (on average, $50 \%$ more) compared to the cultivated areas for all depths assessed (Table 2). Such a result has been reported in several studies (GAZOLLA et al., 2015; BIELUCZYK et al., 2017), and it may be explained by higher stability of the SOM in that area, including the continuous contribution of plant residues with different $\mathrm{C} / \mathrm{N}$ ratios via litter and root inputs, constant vegetation coverage, and the absence of soil disturbance (BIELUCZYK et al., 2017). Similarly, Gazolla et al. (2015) reported that, by having high vegetation and not being anthropized, $\mathrm{CE}$ is an environment favorable for greater accumulation of $\mathrm{C}$ and residues on the soil surface, increasing the OCp content, since a large part of this compartment is formed by particles derived from the residues of the aerial parts and roots of the plants. 
Table 2. Particulate organic carbon (OCp) and mineral-associated organic carbon (OCma) at different soil depths in the areas assessed.

\begin{tabular}{|c|c|c|c|c|}
\hline \multirow{2}{*}{ **Areas } & \multicolumn{4}{|c|}{ Depth (m) } \\
\hline & $0.0-0.05$ & $0.05-0.10$ & $0.10-0.20$ & $0.20-0.40$ \\
\hline & \multicolumn{4}{|c|}{ - } \\
\hline $\mathrm{CE}$ & $15.80 \mathrm{a}^{*}$ & $10.48 \mathrm{a}$ & $8.16 \mathrm{a}$ & $3.73 \mathrm{a}$ \\
\hline SCS & $5.26 \mathrm{c}$ & $3.17 \mathrm{c}$ & $2.47 \mathrm{c}$ & $1.50 \mathrm{c}$ \\
\hline SMS & $4.72 \mathrm{c}$ & $3.08 \mathrm{c}$ & $2.40 \mathrm{c}$ & $1.39 \mathrm{c}$ \\
\hline SCBS & $8.66 \mathrm{~b}$ & $7.75 \mathrm{~b}$ & $4.22 \mathrm{~b}$ & $2.81 \mathrm{~b}$ \\
\hline \multirow[t]{2}{*}{ SCMBCR } & $10.10 \mathrm{~b}$ & $7.73 \mathrm{~b}$ & $4.68 \mathrm{~b}$ & $3.04 \mathrm{~b}$ \\
\hline & \multicolumn{4}{|c|}{---------------------------------- OCma $\left(\mathrm{g} \mathrm{kg}^{-1}\right.$ ) ------------------------------- } \\
\hline $\mathrm{CE}$ & $21.43 \mathrm{a}$ & $17.38 \mathrm{a}$ & $14.00 \mathrm{~b}$ & $15.29 \mathrm{a}$ \\
\hline SCS & $15.75 \mathrm{c}$ & $13.47 \mathrm{~b}$ & $13.19 \mathrm{~b}$ & $12.29 \mathrm{~b}$ \\
\hline SMS & $17.29 \mathrm{bc}$ & $13.19 \mathrm{~b}$ & $12.49 \mathrm{~b}$ & $12.21 \mathrm{~b}$ \\
\hline SCBS & $15.13 \mathrm{c}$ & $18.60 \mathrm{a}$ & $13.37 \mathrm{~b}$ & $12.59 \mathrm{~b}$ \\
\hline SCMBCR & $19.75 \mathrm{ab}$ & $18.76 \mathrm{a}$ & $17.26 \mathrm{a}$ & $12.42 \mathrm{~b}$ \\
\hline
\end{tabular}

*Averages followed by the same letter in the columns and for each depth are not significantly different among the systems assessed based on a t test at $5 \%$ probability. ${ }^{* *}$ SMS-area under NTS with soybean/millet succession. ${ }^{* *}$ CE-native cerrado. ${ }^{* *}$ SCS-area under NTS with soybean/corn succession. ${ }^{* *}$ SCBS-area under NTS with soybean/corn/brachiaria grass succession. ${ }^{* *}$ SCMBCR-area under NTS with soybean/corn/beans/cotton rotation.

Among the cultivated areas, those with a larger number of crops per cycle (SCMBCR and SCBS) are the ones that had highest OCp contents, which were similar to each other and higher (on average, $50 \%$ more) compared to the SCS and SMS areas at all depths (Table 2). As previously discussed, this result shows that the inclusion of species that have an extensive root system (SCBS) and the long-term input of different types of crop residues (SCMBCR) to soils managed under NTS increase the proportion of C with higher lability (CONCEIÇÃO et al., 2005) and total soil $\mathrm{C}$ (Figure 1). Similar results were obtained by several authors, especially Loss (2011), Carmo et al. (2012), Rossi et al. (2012), and Gazolla et al. (2015). The authors cited in this paragraph advocate that managing NTS with incorporation of brachiaria grass results in larger annual addition and retention of plant residues in the soil surface compared to NTS without CLI.

In general, the areas with higher OCma contents were those with $\mathrm{CE}$ and SCMBCR, with these two areas being similar with respect to this parameter up to the $0.10 \mathrm{~m}$ depth (Table 2). Similarly, the SCBS area also had OCma contents comparable to those in the $\mathrm{CE}$ area and higher than those in the areas with SCS and SMS (0.05-0.10 m depth) (Table 2). These results show that the management systems adopted in these areas (SCMBCR and SCBS) have been efficient in recovering and maintaining $C$ on the soil surface. Similar results were reported by Campos et al. (2011) and Gazolla et al. (2015), who also observed increased OCma under NTS with CR and areas under NTS with CLI, respectively, compared to areas with NTS with crop succession. In the case of CLI, these results are justified by the greater contribution of residues coming from grasses, because residues have higher $\mathrm{C} / \mathrm{N}$ and lignin/ $\mathrm{N}$ ratios, resulting in slower residue decomposition, which favors the increase of $\mathrm{C}$ bound to clay and silt associated organo-mineral complexes (SILVA; MENDONÇA, 2007; GAZOLLA et al., 2015). Similarly, Loss (2011) suggested that brachiaria grass in CLI, together with the oxides from the clay 
fraction ( $\mathrm{Fe}$ and $\mathrm{Al}$ ), may provide better conditions for the formation of microaggregates as well as conditions that favor protection and increase of OCma contents.

It is also worth noting that higher OCma in the SCMBCR (0.10-0.20 m depth) and CE (0.20-0.40 $\mathrm{m}$ depth) areas compared to the other areas studied (Table 2). The higher OCma values of the CE and SCMBCR areas in comparison to the other areas at these depths can be correlated to their higher $\mathrm{C}$ contents (Figure 1). In the case of the CE area, this occurs due to the fact that the CE area has not been subjected to soil disturbance, which promotes greater stabilization of the organic matter in the mineral fraction (GAZOLLA et al., 2015).

In general, the $\mathrm{CE}$ area was found to have higher C-HUM, C-HAF, and C-FAF compared to the SCS and SMS areas (0.0-0.40 m depth) (Table 3 ). Other studies have obtained similar results, corroborating the findings of this study (LOSS, 2011; GUARESCHI et al., 2013b; GAZOLLA et al., 2015). Such an effect is due to the greater contribution of litter and the absence of anthropic action in this area, which generate an environment that favors humification. Due to both these factors, he $\mathrm{CE}$ area was also observed to have higher
C-HUM (0.20-0.40 m depth), C-HAF (0.0-0.10 m depth), and C-FAF (0.10-0.20 m depth) compared to the SCBS and SCMBCR areas (Table 3). Gazolla et al. (2015) and Rosset et al. (2016) also found higher contents of humic substances in areas with native vegetation compared to areas with CLI.

The results of C-HUM (0.0-0.05, 0.05-0.10, and 0.10-0.20 m depths), C-HAF (0.10-0.20 and 0.20$0.40 \mathrm{~m}$ depths), and C-FAF (0.0-0.05 and 0.05-0.10 $\mathrm{m}$ depths) for the SCBS, SCMBCR, and CE are similar (Table 3), with higher values observed in the SCMBCR area for C-HUM (0.0-0.05, 0.05-0.10, and $0.10-0.20 \mathrm{~m}$ depths), C-HAF (0.0-0.05 and 0.05-0.10 m depths), and C-FAF (all depths), as well as in the SCBS area for C-HUM (0.0-0.05 and 0.05$0.10 \mathrm{~m}$ depths), C-HAF (0.05-0.10 and 0.10-0.20 $\mathrm{m}$ depths), and C-FAF (all depths), in comparison with the SMS and SCS areas (Table 3). The greater contribution of plant residues with different $\mathrm{C} / \mathrm{N}$ ratios in the SCMBCR and SCBS areas is leading to increased formation of humic substances when compared to the areas with succession of only two cultures (SCS and SMS). The larger supply to the soil of plant residues with higher and/or varying $\mathrm{C} / \mathrm{N}$ and lignin/ $\mathrm{N}$ ratios leads to slow residue decomposition and favors the increase of the recalcitrant fractions of the organic matter in the soil (SILVA; MENDONÇA, 2007; BEZERRA et al., 2013; GAZOLLA et al., 2015). 
Table 3. C contents in the humin (C_HUM), humic acid (C_HAF), and fulvic acid (C_FAF) fractions in different soil usage systems.

\begin{tabular}{|c|c|c|c|}
\hline \multirow[t]{2}{*}{$* *$ Systems assessed } & C_HUM & C_HAF & C_FAF \\
\hline & \multicolumn{3}{|c|}{ 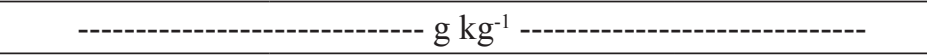 } \\
\hline & \multicolumn{3}{|c|}{$0.0-0.05 \mathrm{~m}$} \\
\hline $\mathrm{CE}$ & $13.70 \mathrm{a}^{*}$ & $6.02 \mathrm{a}$ & $4.12 \mathrm{a}$ \\
\hline SCS & $10.83 \mathrm{~b}$ & $4.46 \mathrm{c}$ & $2.93 \mathrm{~b}$ \\
\hline SMS & $9.89 \mathrm{~b}$ & $4.50 \mathrm{c}$ & $2.82 \mathrm{~b}$ \\
\hline SCBS & $13.53 \mathrm{a}$ & $4.87 \mathrm{bc}$ & $3.93 \mathrm{a}$ \\
\hline \multirow[t]{2}{*}{ SCMBCR } & $15.58 \mathrm{a}$ & $5.24 \mathrm{~b}$ & $3.93 \mathrm{a}$ \\
\hline & \multicolumn{3}{|c|}{$0.05-0.10 \mathrm{~m}$} \\
\hline $\mathrm{CE}$ & $12.96 \mathrm{a}$ & $5.75 \mathrm{a}$ & $3.99 \mathrm{a}$ \\
\hline SCS & $10.34 \mathrm{bc}$ & $3.80 \mathrm{c}$ & $3.11 \mathrm{~b}$ \\
\hline SMS & $8.87 \mathrm{c}$ & $3.59 \mathrm{c}$ & $2.97 \mathrm{~b}$ \\
\hline SCBS & $12.20 \mathrm{ab}$ & $4.75 \mathrm{~b}$ & $3.92 \mathrm{a}$ \\
\hline \multirow[t]{2}{*}{ SCMBCR } & $12.17 \mathrm{ab}$ & $4.84 \mathrm{~b}$ & $3.91 \mathrm{a}$ \\
\hline & \multicolumn{3}{|c|}{$0.10-0.20 \mathrm{~m}$} \\
\hline $\mathrm{CE}$ & $11.12 \mathrm{ab}$ & $4.82 \mathrm{a}$ & $4.16 \mathrm{a}$ \\
\hline SCS & $7.79 \mathrm{c}$ & $3.57 \mathrm{bc}$ & $2.95 \mathrm{c}$ \\
\hline SMS & $7.67 \mathrm{c}$ & $3.41 \mathrm{c}$ & $2.74 \mathrm{~d}$ \\
\hline SCBS & $9.53 \mathrm{bc}$ & $4.02 \mathrm{bc}$ & $3.81 \mathrm{~b}$ \\
\hline \multirow[t]{2}{*}{ SCMBCR } & $11.82 \mathrm{a}$ & $4.27 \mathrm{ab}$ & $3.78 \mathrm{~b}$ \\
\hline & \multicolumn{3}{|c|}{$0.20-0.40 \mathrm{~m}$} \\
\hline $\mathrm{CE}$ & $14.22 \mathrm{a}$ & $3.70 \mathrm{a}$ & $3.49 \mathrm{a}$ \\
\hline SCS & $7.48 \mathrm{~b}$ & $3.15 \mathrm{~b}$ & $2.61 \mathrm{c}$ \\
\hline SMS & $7.30 \mathrm{~b}$ & $3.18 \mathrm{~b}$ & $2.46 \mathrm{c}$ \\
\hline SCBS & $7.58 \mathrm{~b}$ & $3.28 \mathrm{ab}$ & $3.04 \mathrm{~b}$ \\
\hline SCMBCR & $7.58 \mathrm{~b}$ & $3.52 \mathrm{ab}$ & $3.39 \mathrm{a}$ \\
\hline
\end{tabular}

*Averages followed by the same letter in the columns and for each depth are not significantly different among the systems assessed based on a t test at $5 \%$ probability. ${ }^{* *}$ SMS-area under NTS with soybean/millet succession. ${ }^{* *}$ CE-native cerrado. ${ }^{* *}$ SCS-area under NTS with soybean/corn succession. ${ }^{* *}$ SCBS-area under NTS with soybean/corn/brachiaria grass succession. ${ }^{* *}$ SCMBCR-area under NTS with soybean/corn/ beans/cotton rotation.

Similar to the results obtained for OCma (Table 2), the C-HUM and C-HAF in the SCMBCR and SCBS areas were comparable to those in the CE area as well as higher than the respective values in the SCS and SMS areas (Table 3), which shows the higher potential of SCMBCR and SCBS areas to store carbon in the soil as these recalcitrant fractions of SOM strongly interact with the clay fraction (ASSIS et al., 2006), increasing their stabilization in soil and, thus, promoting an increase in the soil
C content (Figure 1). Some studies in literature also reported higher $\mathrm{C}$ values in the humin fraction in areas with CLI compared to areas NTS without CLI (LOSS, 2011; ROSSI et al., 2011; SILVA et al., 2011; BEZERRA et al., 2013; GAZOLLA et al., 2015). The humin fraction is very stable (FONTANA et al., 2006), with it being resistant to biodegradation due to complexation with metal ions or the formation of stable clay-humic complexes (BENITES et al., 2003; BARRETO et al., 2008). 
On the other hand, the higher C-FAF in the SCMBCR and SCBS areas compared to areas with SCS and SMS (Table 3) may be related to the differences between the OCp contents in these areas (Table 2); that is, the higher OCp contents in the areas with SCMBCR and SCBS indicate larger supply of organic residue that is more readily available to mineralization and formation of less recalcitrant humic substances such as C-FAF. Other studies (ROSSI et al., 2011; BEZERRA et al., 2013) have also showed higher C-FAF contents in areas under NTS with CLI compared to NTS without CLI, and have related this trend to the difference in the quality of the straw used in each system.

The highest values for the F1 (0.0-0.10 m depth) and F2 (0.0-0.05 m depth) fractions were found in the $\mathrm{CE}$ area in comparison to the other areas studied (Table 4). The literature also reports higher values for the F1 and/or F2 fractions in areas with native vegetation compared to areas under NTS with and without CLI (LOSS et al., 2013; ROSSET et al., 2016; BIELUCZYK et al., 2017). The authors of these studies attributed this result to the large input of plant material in the cerrado via litter residues. The F1 fraction is a more labile fraction, and it is related to recent additions of organic residues via litter and roots inputs. As the CE area provides enhanced conditions for SOM stability, as previously discussed, the F1 fraction benefits from a better environment to be produced and preserved for longer in this type of vegetation (BIELUCZYK et al., 2017). Bieluczyk et al. (2017) also related the results of F1 and F2 fractions to the results of OCp in terms of liability. In this work, such an effect was also observed, i.e., the CE area had both higher OCp contents (Table 2) and higher F1 fraction compared to the other areas (Table 4).

Table 4. Oxidizable fractions of the soil organic carbon: labile (F1, F2) and recalcitrant (F3, F4) fractions in the areas assessed at the 0.0-0.05 and 0.05-0.10 m depths.

\begin{tabular}{ccccc}
\hline \multirow{2}{*}{ ** Areas } & F1 & F2 & F3 & F4 \\
\cline { 2 - 5 } & - & $0.0-0.05 \mathrm{~m}$ & \\
\hline & & & \\
CE & $9.86 \mathrm{a}^{*}$ & $6.46 \mathrm{a}$ & $5.97 \mathrm{a}$ & $12.84 \mathrm{a}$ \\
SCS & $5.70 \mathrm{~b}$ & $1.66 \mathrm{c}$ & $1.98 \mathrm{~b}$ & $5.93 \mathrm{~b}$ \\
SMS & $5.54 \mathrm{~b}$ & $1.77 \mathrm{c}$ & $2.19 \mathrm{~b}$ & $5.94 \mathrm{~b}$ \\
SCBS & $6.37 \mathrm{~b}$ & $4.35 \mathrm{~b}$ & $2.98 \mathrm{~b}$ & $5.80 \mathrm{~b}$ \\
SCMBCR & $6.50 \mathrm{~b}$ & $4.83 \mathrm{~b}$ & $6.38 \mathrm{a}$ & $11.42 \mathrm{a}$ \\
\hline & & & \\
\hline CE & $6.68 \mathrm{a}$ & $5.46 \mathrm{a}$ & $6.82 \mathrm{ab}$ & $9.89 \mathrm{a}$ \\
SCS & $2.31 \mathrm{c}$ & $1.30 \mathrm{~b}$ & $3.14 \mathrm{c}$ & $9.73 \mathrm{a}$ \\
SMS & $2.38 \mathrm{c}$ & $1.38 \mathrm{~b}$ & $3.08 \mathrm{c}$ & $11.54 \mathrm{a}$ \\
SCBS & $3.98 \mathrm{~b}$ & $4.11 \mathrm{a}$ & $5.64 \mathrm{~b}$ & $11.60 \mathrm{a}$ \\
SCMBCR & $3.55 \mathrm{~b}$ & $3.76 \mathrm{a}$ & $7.58 \mathrm{a}$ & $\mathrm{g} \mathrm{k}$ \\
\hline
\end{tabular}

*Average values followed by the same letter in the columns and for each depth are not significantly different among the systems assessed based on a t test at $5 \%$ probability. ${ }^{* *}$ SMS-area under NTS with soybean/millet succession. ${ }^{* *}$ CE-native cerrado. ${ }^{* *}$ SCSarea under NTS with soybean/corn succession. "*SCBS-area under NTS with soybean/corn/brachiaria grass succession. ${ }^{* *}$ SCMBCRarea under NTS with soybean/corn/beans/cotton rotation. 
Again, it was observed that the SCMBCR and SCBS areas had carbon contents in the F1 (0.05$0.10 \mathrm{~m}$ depth) and F2 (0.0-0.10 $\mathrm{m}$ depth) fractions that are similar between each other and larger than those found in the areas with SCS and SMS (Table 4). It was also observed that these areas (SCMBCR and SCBS) are equivalent to the CE area as regards to the $\mathrm{C}$ contents in the $\mathrm{F} 2$ fraction (Table 4). This result indicates greater input of plant material with high lability in these areas, which corroborates the OCp (Table 2) and FAF (Table 3) results. Others have also reported higher contents of F1 and/ or F2 fractions in areas under NTS with CLI in comparison to NTS areas without CLI, as well as similarities in these fractions for NTS with CLI areas and areas with native vegetation (LOSS et al., 2013; ROSSET et al., 2016; BIELUCZYK et al., 2017). According to Bieluczyk et al. (2017), higher F1 and F2 contents occur due to the contribution of the residues from the roots and aerial parts of the species in rotation and brachiaria grass in the case of CLI, which contribute to the increase of carbon supply during the inter-harvesting period, thus ensuring an increase of the more labile fractions of SOM under conservation agriculture systems. As brachiaria grass residues with high $\mathrm{C} / \mathrm{N}$ ratio are added to the soil surface in the areas with CLI, such carbon forms tend to be predominant and persist in the soil for longer periods due to the chemical recalcitrance of their organic composition and the quantity of organic residue added to the soil (BIELUCZYK et al., 2017).

Regarding the F3 and F4 fractions of soil carbon, SCMBCR and CE areas were found to be similar to each other and superior to the other areas at the soil surface (0.0-0.05 $\mathrm{m}$ depth) (Table 4). There is good agreement between these results and those of soil total C (Figure 1). These findings can also be correlated with the different crops in rotation that contribute to the soil carbon under NTS with organic materials of varying quality $(\mathrm{C} / \mathrm{N}$ ratio and lignin and polyphenol contents, among others), which changes their decomposition rates, and leads to increased carbon stocking in the soil (Figure 1) through the formation of more recalcitrant humic substances (Tables 2 and 3). On the other hand, the F3 and F4 oxidizable fractions provided greater differentiation between the areas with SCMBCR and SCBS at the more superficial depth $(0-0.05 \mathrm{~m})$, with the area with SCMBCR, which is more strongly influenced by the contribution of residues from the aerial part of the crops, having 53\% and $49 \%$ more C-F3 and C-F4, respectively, compared to the SCBS area. When studying NTS areas with and without CLI, Loss et al. (2013) reported a pattern that contrasts with these results. These authors observed that the area under NTS with CLI had higher C-F3 and C-F4 contents. This divergent pattern compared to the results of this study may be due to the fact that the NTS area with CLI was under crop rotation, while the CLI area studied in the present work was under a SCBS. Given the above, on a general overview, the importance of $\mathrm{CR}$ for the accumulation of $\mathrm{C}$ in the more recalcitrant factions of SOM in areas under NTS becomes apparent.

At the 0.05-0.10 $\mathrm{m}$ depth, differences among the areas were only observed for the $\mathrm{F} 3$ fraction, again with the SCMBCR and SCBS areas being similar to the $\mathrm{CE}$ area and having higher values compared to the areas with SCS and SMS (Table 4). These results agree with the patterns observed for OCma (Table 2), HUM, and C-FAH (Table 3), where, again, it was evident that greater supply of organic residues with different quality promoted the formation and stability of more recalcitrant C forms. Similarly, when studying NTS areas with and without CLI in cerrado regions, Loss et al. (2013), Batista et al. (2014), and Bieluczyk et al. (2017) observed that the addition to the soil of organic residues with different $\mathrm{C} / \mathrm{N}$ ratios led to slower mineralization, reducing the development of labile fractions and increasing the formation of more recalcitrant organic substances, having strong correlation with the level of chemically stable humic substances, such as humin. 
As for the higher levels of recalcitrant fractions (F3 and F4) in the CE areas compared to the areas with SCS, SMS (0.0-0.10 m depth), and SCBS (0.0-0.05 $\mathrm{m} \mathrm{depth),} \mathrm{it} \mathrm{should} \mathrm{be} \mathrm{noted} \mathrm{that} \mathrm{this}$ result indicates the long-term accumulation of organic compounds with high chemical stability and molecular weight, resulting from SOM decomposition and humification (RANGEL et al., 2008) in the area that has not been subjected to anthropic action. Similarly, other studies have reported higher $\mathrm{C}$ contents in the $\mathrm{F} 3$ and $\mathrm{F} 4$ fractions in areas with native vegetation compared to areas under NTS with or without CLI (LOSS et al., 2013; ROSSET et al., 2016; BIELUCZYK et al., 2017).

\section{Conclusions}

The no-tillage system with crop rotation, followed by the no-tillage system with croplivestock integration, showed greater potential to change/increase the total soil carbon content by modifying or increasing the $\mathrm{C}$ contents in the granulometric, humic, and oxidizable fractions of SOM compared to the other areas under non-tillage system with crop succession.

The areas under no-tillage system with soybean/ corn and soybean/millet successions had a similar pattern in the context of $\mathrm{C}$ accumulation in the soil as well as in the compartments of SOM evaluated.

\section{References}

ASSIS, C. P.; JUCKSCH, I.; MENDONÇA, E. S.; NEVES, J. C. L. Carbono e nitrogênio em agregados de Latossolo submetido a diferentes sistemas de uso e manejo. Pesquisa Agropecuária Brasileira, Brasília, v. 41, n. 10, p. 1541-1550, 2006.

BARRETO, A. C.; FREIRE, M. B. G. S.; NACIF, P. G. S.; ARAÚJO, Q. R.; FREIRE, F. J.; INÁCIO, E. S. B. Fracionamento químico e físico do carbono orgânico total em um solo de mata submetido a diferentes usos. Revista Brasileira de Ciência do Solo, Viçosa, MG, v. 32, n. 4, p. 1471-1478, 2008.

BATISTA, I.; CORREIA, M. E. F.; PEREIRA, M. G.; BIELUCZYK, W.; SCHIAVO, J. A.; ROUWS, J.
R. C. Frações oxidáveis do carbono orgânico total e macrofauna edáfica em sistema de integração lavourapecuária. Revista Brasileira de Ciência do Solo, Viçosa, MG, v. 38, n. 3, p. 797-809, 2014.

BENITES, V. M.; MÁDARI, B.; MACHADO, P. L. O. A. Extração e fracionamento quantitativo de substâncias húmicas do solo: um procedimento simplificado e de baixo custo. Rio de Janeiro: EMBRAPA Solos, 2003. 7 p. (EMBRAPA Solos. Comunicado técnico, 16).

BEZERRA, R. P. M.; LOSS, A.; PEREIRA, M. G.; PERIN, A. Formas de carbono em latossolo sob sistemas de plantio direto e integração lavoura-pecuária no cerrado, Goiás. Semina: Ciências Agrárias, Londrina, v. 34, n. 6, p. 2637-2654, 2013.

BIELUCZYK, W.; PEREIRA, M. G.; GUARESCHI, R. F.; BONETTI, J. A.; FREÓ, V. A.; SILVA NETO, E. C. Frações oxidáveis e granulométricas da matéria orgânica em sistemas de integração lavoura-pecuária. Semina: Ciências Agrárias, Londrina, v. 38, n. 2, p. 607-622, 2017.

BRANCALIÃO, S. R.; MORAES, M. H. Alterações de alguns atributos físicos e das frações húmicas de um Nitossolo vermelho na sucessão milheto-soja em sistema plantio direto. Revista Brasileira de Ciência do Solo, Viçosa, MG, v. 32, n. 1, p. 393-404, 2008.

BRANCALIÃO, S. R.; MORAES, M. H.; LEMOS, L. B. Alterações de propriedades físicas de um Nitossolo vermelho pela sucessão milheto-soja na fase de implantação do sistema de semeadura direta. Irriga, Botucatu, v. 12, n. 3, p. 409-421, 2007.

BRESSAN, S. B.; NÓBREGA, J. C. A.; NÓBREGA, R. S. A.; BARBOSA, R. S.; SOUSA, L. B. Plantas de cobertura e qualidade química de Latossolo Amarelo sob plantio direto no cerrado maranhense. Revista Brasileira de Engenharia Agrícola e Ambiental, Campina Grande, v. 17, n. 4, p. 371-378, 2013.

CAETANO, J. O.; BENITES, V. M.; SILVA, G. P.; SILVA, I. R.; ASSIS, R. L.; CARGNELUTTI FILHO, A. Dinâmica da matéria orgânica de um neossolo quartzarênico de cerrado convertido para cultivo em sucessão de soja e milheto. Revista Brasileira de Ciência do Solo, Viçosa, MG, v. 37, n. 5, p. 1245-1255, 2013.

CAMBARDELlA, C. A.; ELLIOTT, E. T. Particulate soil organic-matter changes across a grassland cultivation sequence. Soil Science Society of America Journal, Madison, v. 56, n. 1, p. 777-783, 1992.

CAMPOS, B. C.; AMADO, T. J. C.; BAYER, C.; NICOLOSO, R. S.; FIORIN, J. E. Carbon stock and its compartments in a subtropical oxisol under long-term tillage and crop rotation systems. Revista Brasileira de 
Ciência do Solo, Viçosa, MG, v. 35, n. 3, p. 805-817, 2011.

CARMO, F. F.; FIGUEIREDO, C. C.; RAMOS, M. L. G.; VIVALDI, L. J.; ARAÚJO, L. G. Frações granulométricas da matéria orgânica em Latossolo sob plantio direto com gramíneas. Bioscience Journal, Uberlândia, v. 28, n. 3, p. 420-431, 2012.

CARNEIRO, M. A. C.; SOUZA, E. D.; PAULINO, H. B.; SALES, L. E. O.; VILELA, L. A. F. Atributos indicadores de qualidade em solos de cerrado no entorno do parque nacional das emas, Goiás. Bioscience Journal, Uberlândia, v. 29, n. 6, p. 1857-1868, 2013.

CECCON, G.; STAUT, L. A.; SAGRILO, E.; MACHADO, L. A. Z.; NUNES, D. P.; ALVES, V. B. Legumes and forage species sole or intercropped with corn in soybean-corn succession in midwestern Brazil. Revista Brasileira de Ciência do Solo, Viçosa, MG, v. 37, n. 1, p. 204-212, 2013.

CHAN, K. Y.; BOWMAN, A.; OATES, A. Oxidizible organic carbon fractions and soil quality changes in an Paleustalf under different pasture leys. Soil Science, Baltimore, v. 166, n. 1, p. 61-67, 2001.

CONCEIÇÃO, P. C.; AMADO, T. J. C.; MIELNICZUK, J.; SPAGNOLLO, E. Qualidade do solo em sistemas de manejo avaliada pela dinâmica da matéria orgânica e atributos relacionados. Revista Brasileira de Ciência do Solo, Viçosa, MG, v. 29, n. 5, p. 777-788, 2005.

DONAGEMA, G. K.; CAMPOS, D. V. B.; CALDERANO, S. B.; TEIXEIRA, W. G.; VIANA, J. H. M. (Org.). Manual de métodos de análise de solos. 2. ed. Rio de Janeiro: EMBRAPA Solos, 2011. 230 p.

FONTANA, A.; PEREIRA, M. G.; LOSS, A.; CUNHA, T. J. F.; SALTON, J. C. Atributos de fertilidade e frações húmicas de um Latossolo Vermelho no Cerrado. Pesquisa Agropecuária Brasileira, Brasília, v. 41, n. 5, p. 847-853, 2006.

FRANCHINI, J. C.; COSTA, J. M.; DEBIASI, H. Rotação de culturas: prática que confere maior sustentabilidade à produção agrícola no Paraná. Informações Agronômicas, Piracicaba, v. 134, n. 1, p. 1-13, 2011.

GAZOLlA, P. R.; GUARESCHI, R. F.; PERIN, A. Estoque de carbono e atributos físicos de um Latossolo Vermelho em diferentes sistemas de manejo. Revista Brasileira de Ciências Agrárias, Recife, v. 8, n. 2, p. 229235, 2013.

GAZOLlA, P. R.; GUARESCHI, R. F.; PERIN, A.; PEREIRA, M. G.; ROSSI, C. Q. Frações da matéria orgânica do solo sob pastagem, sistema plantio direto e integração lavoura-pecuária. Semina: Ciências Agrárias, Londrina, v. 36, n. 2, p. 693-704, 2015.
GUARESCHI, R. F.; PEREIRA, M. G.; PERIN, A. Deposição de resíduos vegetais, matéria orgânica leve, estoques de carbono e nitrogênio e fósforo remanescente sob diferentes sistemas de manejo no cerrado goiano. Revista Brasileira de Ciência do Solo, Viçosa, MG, v. 36, n. 3, p. 909-920, 2012a.

Estoque de carbono em Latossolo Vermelho Distroférrico sob diferentes sistemas de manejo. Revista Brasileira de Ciências Agrárias, Recife, v. 7, n. 4, p. 597 602, 2012b.

Frações da matéria orgânica em áreas de Latossolo sob diferentes sistemas de manejo no Cerrado do estado de Goiás. Semina: Ciências Agrárias, Londrina, v. 34, n. 6, p. 2615-2628, 2013.

Oxidizable carbon fractions in Red Latosol under different management systems. Revista Ciência Agronômica, Fortaleza, v. 44, n. 2, p. 242-250, 2013a.

HIRAKURI, M. H.; DEBIASI, H.; PROCÓPIO, S. O.; FRANCHINI, J. C.; CASTRO, C. Sistemas de produção: conceitos e definições no contexto agrícola. Londrina: EMBRAPA Soja, 2012. 24 p. (Documentos/ EMBRAPA Soja).

LOSS, A. Dinâmica da matéria orgânica, fertilidade e agregação do solo em áreas sob diferentes sistemas de uso no cerrado goiano. 2011. Tese (Doutorado em Agronomia - Ciência do Solo) - Universidade Federal Rural do Rio de Janeiro, Seropédica.

LOSS, A.; PEREIRA, M. G.; PERIN, A.; BEUTLER, S. J.; ANJOS, L. H. C. Carbon, nitrogen and natural abundance of $13 \mathrm{C}$ e $15 \mathrm{~N}$ of light-fraction organic matter under no-tillage system and crop-livestock integration in the Cerrado. Acta Scientiarum. Agronomy, Maringa, v. 34, n. 4, p. 468-474. 2012.

Oxidizable carbon and humic substances in rotation systems with brachiaria/livestock and pearl millet/no livestock in the Brazilian Cerrado. Spanish Journal of Agricultural Research, Madrid, v. 11, n. 1, p. 217-231, 2013.

MARCELO, A. V.; CORÁ, J. E.; FERNANDES, C.; MARTINS, M. R.; JORGE, R. F. Crop sequences in notillage system: effects on soil fertility and soybean, maize and rice yield. Revista Brasileira de Ciência do Solo, Viçosa, MG, v. 33, n. 2, p. 417-428, 2009.

MARIA, I. C.; DI TROCCHIO, M. F.; PIEDADE, R. C.; DUARTE, A. P. Sobressemeadura de braquiária em soja para produção de palha em sistema plantio direto na região do Médio Paranapanema, SP. Boletim Científico, Campinas, v. 17, n. 1, p. 1-20, 2012. 
PEREIRA, M. G.; LOSS, A.; BEUTLER, S. J.; TORRES, J. L. R. Carbono, matéria orgânica leve e fósforo remanescente em diferentes sistemas de manejo do solo. Pesquisa Agropecuária Brasileira, Brasília, v. 45, n. 5, p. 508-514, 2010.

RANGEL, O. J. P.; SILVA, C. A.; GUIMARÃES, P. T. G.; GUILHERME, L. R. G. Frações oxidáveis do carbono orgânico de Latossolo cultivado com cafeeiro em diferentes espaçamentos de plantio. Ciência $e$ Agrotecnologia, Lavras, v. 32, n. 2, p. 429-437, 2008.

ROSSET, J. S.; LANA, M. C.; PEREIRA, M. G.; SCHIAVO, J. A.; RAMPIM, L.; SARTO, L. V. M. Frações químicas e oxidáveis da matéria orgânica do solo sob diferentes sistemas de manejo, em Latossolo Vermelho. Pesquisa Agropecuária Brasileira, Brasília, v. 51, n. 9, p. 1529-1538, 2016.

ROSSI, C. Q.; PEREIRA, M. G.; GIACOMO, S. G.; BETTA, M.; POLIDORO, J. C. Frações húmicas da matéria orgânica do solo cultivado com soja sobre palhada de braquiária e sorgo. Bragantia, Campinas, v. 70, n. 3, p. 622-630, 2011.

. Frações lábeis da matéria orgânica em sistema de cultivo com palha de braquiária e sorgo. Revista Ciência Agronômica, Fortaleza, v. 43, n. 1, p. 38-46, 2012.

ROZANE, D. E.; CENTURION, J. F.; ROMUALDO, L. M.; TANIGUCHI, C. A. K.; TRABUCO, M.; ALVES, A. U. Estoque de carbono e estabilidade de agregados de um Latossolo Vermelho distrófico, sob diferentes manejos. Bioscience Journal, Uberlândia, v. 26, n. 1, p. 24-32, 2010.

SEBEN JUNIOR, G. F.; CORÁ, J. E.; LAL, R. Soil aggregation according to the dynamics of carbon and nitrogen in soil under different cropping systems. Pesquisa Agropecuária Brasileira, Brasília, v. 51, n. 9, p. 1652-1659, 2016.
SILVA, E. F.; LOURENTE, E. P. R.; MARCHETTI, M. E.; MERCANTE, F. M.; FERREIRA, A. K. T.; FUJII, G. C. Frações lábeis e recalcitrantes da matéria orgânica em solos sob integração lavoura-pecuária. Pesquisa Agropecuária Brasileira, Brasília, v. 46, n. 10, p. 13211331, 2011.

SILVA, I. R.; MENDONÇA, E. S. Matéria orgânica do solo. In: NOVAIS, R. F.; ALVAREZ, V. V. H.; BARROS, N. F.; FONTES, R. L. F.; CANTARUTTI, R. B.; NEVES, J. C. L. (Ed.). Fertilidade do solo. Viçosa, MG: Sociedade Brasileira de Ciência do Solo, 2007. p. 275-374.

SIQUEIRA NETO, M.; SCOPEL, E.; CORBEELS, M.; CARDOSO, A. N.; DOUZET, J. M.; FELLER, C.; PICCOLO, M. C.; CERRI, C. C.; BERNOUX, M. Estoques de carbono do solo sob plantio direto em sistemas de cultivo no Cerrado do Brasil: Uma avaliação sincrônica na exploração. Soil and Tillage Research, Amsterdam, v. 110, n. 1, p. 187-195, 2010.

SOUZA, E. D.; COSTA, S. E. V. G. A.; ANGHINONI, I.; CARVALHO, P. C. F.; ANDRIGUETI, M.; CAIO, E. Estoque de carbono orgânico e de nitrogênio no solo em sistema de integração lavoura-pecuária em plantio direto, submetido a intensidades de pastejo. Revista Brasileira de Ciência do Solo, Viçosa, MG, v. 33, n. 6, p. 18291836, 2009.

SWIFT, R. S. Organic matter characterization. In: SPARKS, D. L.; PAGE, A. L.; HELMKE, P. A.; LOEPPERT, R. H.; SOLTANPOUR, P. N.; TABATABAI, M. A.; JOHNSTON, C. T.; SUMNER, M. E. (Ed.). Methods of soil analysis. Madison: American Society of Agronomy, Soil Science Society American, 1996. p. 1011-1020. (SSA Book series, 5).

TIRLONI, C.; VITORINO, A. C. T.; BERGAMIN, A. C.; SOUZA, L. C. F. Physical properties and particlesize fractions of soil organic matter in crop-livestock integration. Revista Brasileira de Ciência do Solo, Viçosa, MG, v. 36, n. 4, p. 1299-1309, 2012. 